内山 卓也 ${ }^{1)}$, 吉岡 宏真 ${ }^{1)}$, 布川 知史 ${ }^{2)}$, 加藤 天美 ${ }^{2)}$

1）近畿大学医学部堺病院脳神経外科, 2) 近畿大学医学部脳神経外科

\title{
Clinical Epidemiology and Treatments for Spasticity
}

\author{
Takuya Uchiyama, M.D., Ph.D. ${ }^{1)}$, Hiromasa Yoshioka, M.D., Ph.D. ${ }^{1)}$, Norihito Fukawa, M.D. ${ }^{2)}$, and \\ Amami Kato, M.D., Ph.D. ${ }^{2)}$ \\ 1) Department of Neurosurgery, Kindai University Sakai Hospital, 2) Department of Neurosurgery, Kindai University, Fac- \\ ulty of Medicine
}

Spasticity manifests primarily as hypertonia accompanying central nervous system disorders such as cerebrovascular accident (CVA) and traumatic brain injury (TBI), and is a neurological symptom that is frequently encountered by neurosurgeons in the course of their everyday practices.

The exact prevalence of spasticity in Japan is not known, but reports of cases in other countries indicate that over $35 \%$ of patients who have suffered CVA and $75 \%$ of patients with severe TBI exhibit spasticity. A 2014 study of patients in Japan who had suffered CVA surveyed approximately 1.18 million patients and reported that those with spasticity alone numbered over 410,000, while the number of patients with severe spasticity originating from a cause without CVA was estimated to be over 80,000. To date, only approximately 50,000 spasticity patients have been treated with botulinum neurotoxin therapy and only around 1,700 have been treated with intrathecal baclofen therapy. Based on these numbers, it is possible that the benefits of these therapies are being made available to fewer patients in Japan compared to Europe and the US.

In order to continue developing these therapies for spasticity, we need to be familiar with the characteristics of various treatment methods used to treat spasticity, and to create frameworks for regional alliances that focus primarily on education and rehabilitation programs targeting spasticity treatment and that involve the patient, the patient's family, and medical staff.

(Received August 1, 2017 ; accepted September 6, 2017)

Key words : spasticity, epidemiology, intrathecal baclofen, botulinum toxin, peripheral neurotomy Jpn J Neurosurg（Tokyo）26:882-891, 2017

\section{はじめに}

痤縮は脳卒中・脳性麻痺・頭部外傷・脊髄損傷・多発 性硬化症や神経変性疾患などが原因となる中枢神経障害 に伴う筋緊張光進を主体とし, 脳神経外科医が日常診療 で遭遇する機会の非常に多い病態であるが，本邦での痙
縮の正確な有病率はわかっていないのが現状である。そ こで本稿では海外の痤縮の有病率から症例数を概算し, 痤縮治療の浸透度を推測, 痤縮治療の適応, 今後の痤縮 治療の展望と課題について概説する.

連絡先：内山卓也， $=590-0132$ 堺市南区原山台 2-3-1＼cjkstart近畿大学医学部堺病院脳神経外科

Address reprint requests to: Takuya Uchiyama, M.D., Ph.D., Department of Neurosurgery, Kindai University Sakai Hospital, 2-7-1 Harayamadai, Minami-ku, Sakai-shi, Osaka 590-0132, Japan. 


\section{痙縮の病態生理}

痤縮は，中枢神経である上位運動ニューロンの障害に より運動速度依存性の伸張反射の充進を呈し, 腱反射の 充進を伴う運動障害と Lance ${ }^{18)}$ により定義され，この定 義は現在も広く使用されている。病縮は, 上位運動 ニューロン障害の発症後, 一定期間を経て出現する。 中 枢神経障害発症から痤縮の発生までに時間差が生じる理 由として, 春髄や大脳のレベルでの神経の再構成・可塑 性の出現, 求心性軸索の発芽などが示唆されている2 ${ }^{2}$.

痤縮の病態生理であるが，上肢では屈筋群，下肢では 伸筋群に筋緊張元進を認めるのは, 屈筋群と伸筋群の筋 肉量の違いや，それぞれの筋紡錘の数の違いにもよると されている，また脳卒中後の痤縮では過度の筋緊張を認 めるが筋のスパズムは認めにくく，一方春髄病変による 下肢疰縮では, 筋のスパズムが主体となり, 原因が脳と 脊髄では, 痤縮のメカニズムが違うと考元られる29)43). そこで, 脊髄および末梢での伸展反射に関連する要因と 脳からのコントロール機能に関連する要因とに分けてま とめると,

(1)脊髄および末梢での伸展反射に関連する要因

i ) 促通系

1） $\gamma$ 運動ニューロンの活動性の六進

2） $\alpha$ 運動ニューロン自身の過剩興奮

3 ) 筋紡錘感受性の上昇

4 ) Ia 群線維発芽現象

5 ）シナプス後膜の感受性の上昇

ii ）抑制系

1) Ia 群線維終末に対するシナプス前抑制の減少

2) Ib 抑制の低下

3 ）相反性抑制の低下

4 ）反回抑制の低下

(2)脳からのコントロール機能に関連する要因

i ) 促通系

1）内側網様体脊髄路

2 ) 前庭脊髄路

ii ）抑制系

1）皮質網様体路

2 ）背側網様体脊髄路

以上が，主なものと考えられている7226)33134)。しかし これらは複雑に関係しており, 病態生理のすべてが解明 されては扮らず，さらなる痤縮のメカニズムの解明は新 しい治療法の開発などにおいても重要な課題と考える.

\section{痤縮の疫学}

痤縮治療の浸透度を推測するには, 痤縮患者がどの程 度存在するのかを知ることが重要であると考える，しか し本邦での痤縮の正確な有病率はわかっていない, 海外 の報告からは, 脳卒中の $35 \%$ 以上 $\left.{ }^{39} 41\right)$, 重症の頭部外傷 の $75 \%{ }^{40)}$, 脳性麻痺の $90 \%{ }^{10)}$, 脊髄損傷の $80 \%{ }^{21)}$, 多 発性硬化症の $90 \%{ }^{30)}$ の患者が痤縮を呈すると報告され ている。脳卒中患者は 2014 年の厚生労㗢省の調査では 約 118 万人と報告されており, 単純計算すると脳卒中後 の疰縮患者だけでも 41 万人以上いることとなる，その 他, 脳卒中後以外の原因に基づく重度痤縮症例が 8 万人 以上いると推計されている ${ }^{36)}$.

この点をふまえても, 本邦での痤縮治療は現在まで漸 増傾向にはあるが，ボッリヌス療法は約 5 万症例，バク ロフェン髄腔内投与療法（intrathecal baclofen：ITB）療 法は約 1,700 症例にとどまっており, これらの治療の恩 恵を受けている患者は少ないと考元られ, 日常診療で痤 縮患者を診ることの多い脳神経外科医にとつて痤縮治療 について理解し, 患者に提供できる環境を整えるのが今 後の重要な課題と考える.

\section{痙縮に対する治療}

痤縮治療にはリハビリテーションを中心として内服治 療以外に, A 型ボッリヌス療法 (botulinum neurotoxin-A therapy：BoNT-A), ITB, 選択的末梢神経縮小術 (selective peripheral neurotomy: SPN), 選択的後根切断術 (selective dorsal rhizotomy：SDR）などがあり，われわれ はその治療体系を病縮の局在と治療の可逆性に加え治療 の調節性により分類している (Fig. 1).

脳卒中治療ガイドライン 2015 では内服治療と BoNTA がグレード A, ITB がグレード B で, 脳性麻痺治療ガ イドライン 2014 では, BoNT-A がグレード A, ITB と SDRがグレードBで推奨されている.

\section{選択的末梢神経縮小術（SPN）}

限局した神経支配領域に生じている痤縮に対しての手 術方法であり, 過剩興奮した反射弓に対して選択的に運 動神経を手術により縮小し, 適度な指令が伝わるように 神経のバランスを調節する手術である.

末梢の運動神経は, 単に脊䯣からの運動神経のみから 構成されているのではなく, 筋や腱からの中枢へ向かう 固有知覚線維も含んでいる。末梢神経縮小術では, この 


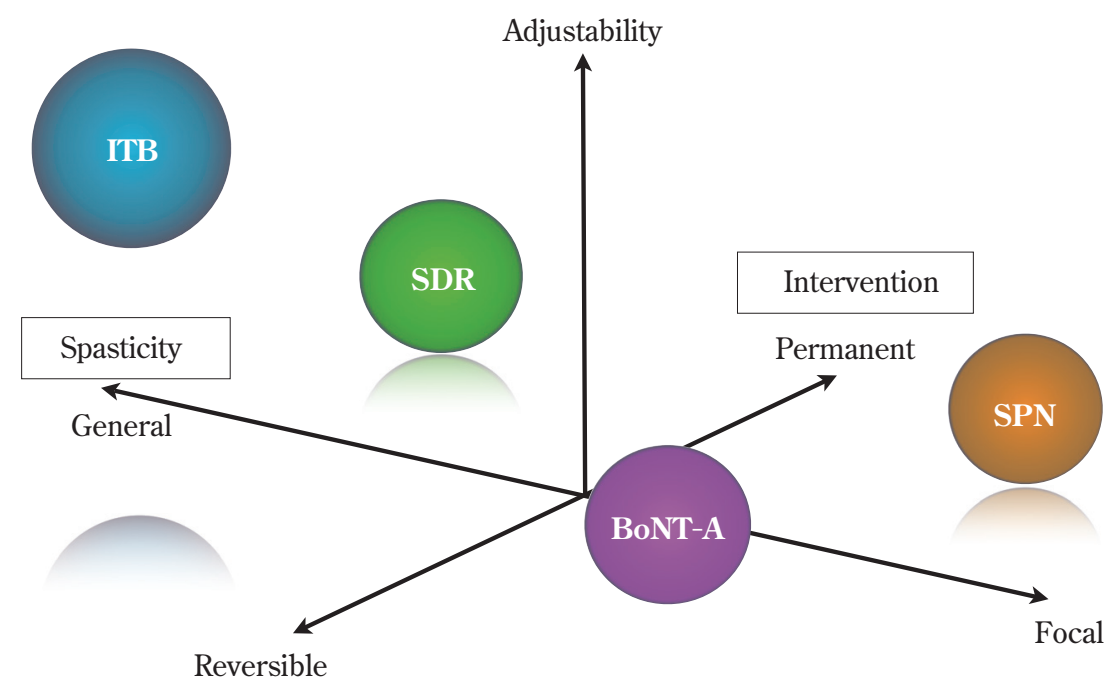

Fig. 1 Therapeutic options in the treatment of spasticity

BoNT-A : botulinum neurotoxin-A, ITB : intrathecal baclofen, SDR : selective dorsal rhizotomy, SPN : selective peripheral neurotomy

反射弓の末梢へ向かう線維および一部の中枢へ向かう線 維を含む神経を 4 分の $3 \sim 5$ 分の 4 程度に縮小することに より反射の克進を抑え，痤縮の改善を図る。このとき， 運動神経の縮小による筋力低下が懸念されるが，4 分の 1 5 分の 1 程度の運動神経線維を残せば, 筋本来の運動 機能は保つことができる.

脳血管障害後や痤直型脳性麻痺例の尖足，内反，足ク ローヌスは歩行障害や日常生活動作の主な障害となり, これらの症状に対する選択的脛骨神経縮小術は，痤縮の 改善や歩行速度および足関節可動域の改善をきたし，長 期間にわたり痤縮をコントロールすることができ $ろ^{8) 12) 35)}$.

SPN は脳卒中後の片麻痺を代表とする局所性の痤縮 に適応があるが, 最近は低侵襲である BoNT-A 治療が国 内でも保険適応となり, 同等の効果が得られるために行 わ扎る機会が少なくなっている。しかし，BoNT-A 治療 は高価であり，3〜4 カ月ごとに施注することとなるの で，単回の治療で完結できる利点を考慮すると，成人例 における足関節内反・尖足に対する脛骨神経縮小術は有 効性が高く, 手術適応があると考えている (Fig. 2)。た だし，小児例では，成人例に比べ神経の再生機構が強 (4)13)術後再発の危険性が高いため現在は行われなく なっている。

\section{選択的後根切断術（SDR）}

SDR は L2〜S2 の春髄後根を選択的に 50〜 60\%程度切 離し，有害な脊髄反射を低減させ痤縮を緩和する手術で ある.SDRの適応は痤直型小児脳性麻痺で，その中でも 中〜重症度の下肢対麻痺の患児が最もよい適応とされ， 次に体幹にも痤性が認められる四肢麻痺の患児とされて いる。これは長脊髄反射（long spinal reflex）を介した異 常反射も改善するために，下肢の手術で上肢の痤縮改善 のみならず発語・情動などの高次脳機能改善にも効果が 期待できるからである。

手術適応年齢であるが，運動機能の評価が可能となる 2 歳半〜学童期前半までが理想である。1 10 歳以上は関節 拘縮などの不可逆的な器質的変化を伴うことが多く, 疼 痛緩和目的以外は適応を慎重にするべきである22)

SDR の治療効果であるが一般にその有効性はきわめ て高く, 約 $80 \%$ で有効と判定されている.さらに術後の 理学療法が適切に施行されていれば痤性の再発は，約 $2 \sim 3 \%$ 程度に抑えられ，永続的な痤性の低下が得られ $3^{19)}$.

\section{バクロフェン髄腔内投与療法（ITB）}

バクロフェンは $\mathrm{GABA}_{\mathrm{B}}$ 受容体に対する競合薬である. その抗痤縮作用は脊髄後角に多く分布する GABAニュー 

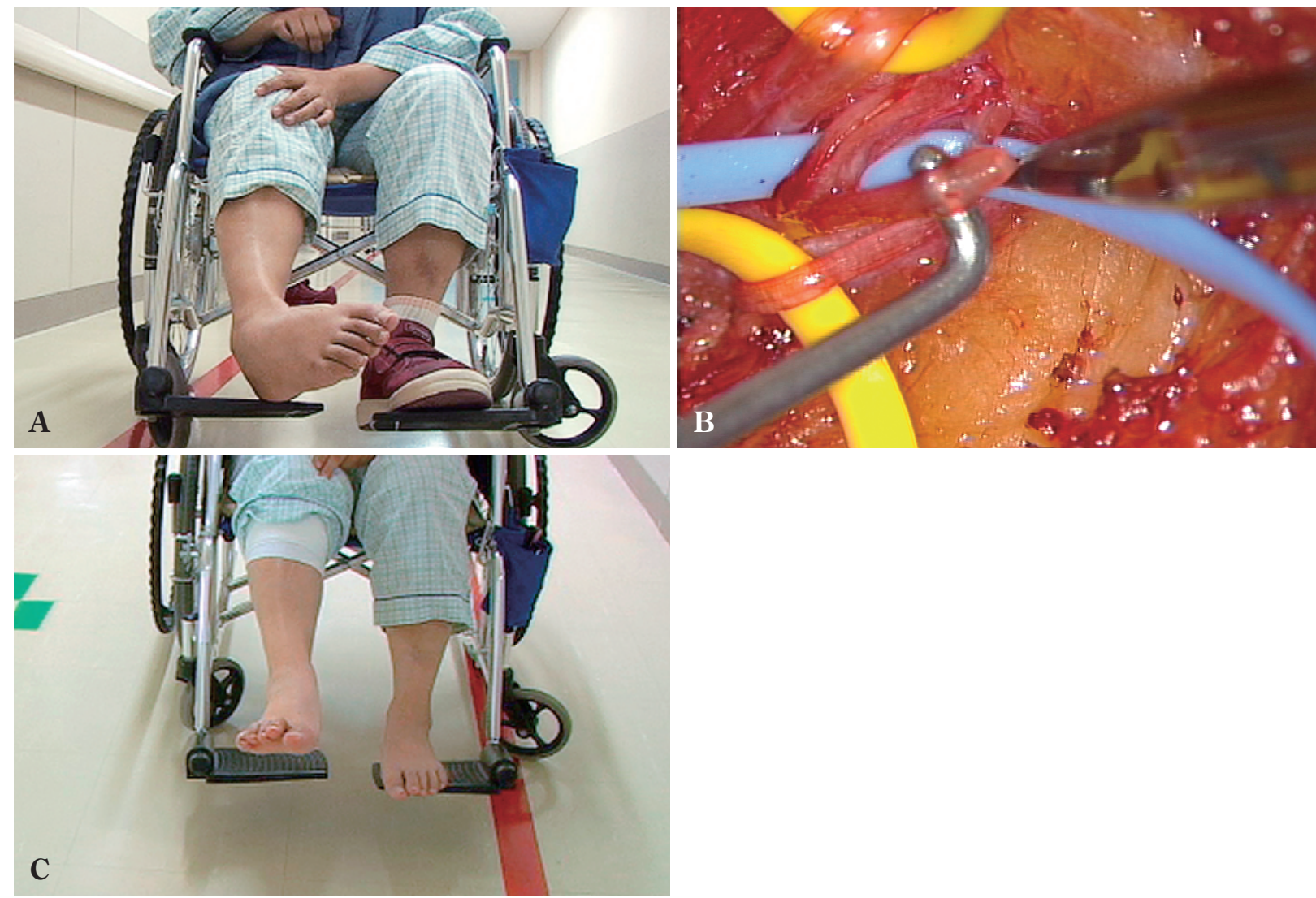

Fig. 2 The posture of the ankle joint in a patient with right statistic hemiparesis after intracerebral hemorrhage

A : Before selective tibial neurotomy.

B : Intraoperative photograph : partial denervation of posterior tibial nerve.

C : Two weeks after selective tibial neurotomy.

ロンに作用し，末梢からの Ia 線維を求心路とする oligosynaptic reflexを抑制し， $\gamma$ 運動ニューロンの活性化を低 下させることにより抗痤縮効果をきたす。バクロフェン を髄腔内に直接投与すると, 脊髄後角に作用し, 経口投 与の 100 分の 1 程度の量で痓縮の緩和が得られる。

本邦でも 2006 年 4 月に保険適応となり, 約 10 年が経 過しさまざまな原因疾患による痤縮例に投与され国内で は約 1,700 例に実施されている. 日本の 2005 2014 年ま での 1,065 例の全例調査の内訳では, 概略であるが脳由 来では脳血管障害と脳性麻痺が $40 \%$ 程度でほぼ同数, 変 性疾患は遺伝性痤性対麻痺が $80 \%$ 程度, 脊䯣由来は脊髄 損傷が $85 \%$ 程度となっている。

\section{1 脳血管障害}

脳卒中後の痓縮は多くは片麻痺症例である。片麻痺の 上肢または下肢の局所性痤縮には, BoNT-A 療法で治療 される機会が多い。しかし体幹および上下肢に及ぶ痤縮
症例には BoNT-A注射の施注筋が増えることにより投与 量も増え, 1 回投与量の上限もあるために, 十分な治療 効果が得られないことがある。このような症例では ITB 療法が適応ではないかと考える。上肢の痤縮を治療する 場合は, カテーテル先端をできるだけ下位䅡椎〜上位胸 椎の高さに留置することが重要となる。われわれの施設 でも脳卒中後の片麻痺症例において健常肢の脱力などを 生じることなく患側の痤縮の改善を認め海外の報告 ${ }^{24)}$ と 一致している.この理由として, 痤縮発症後の病的反射 経路に GABA sensitive receptor が増加し, バクロフェン がこの病的な反射回路を選択的に抑制するために健常な 筋への影響が少ないと考えられている ${ }^{20)}$.

\section{2 頭部外傷}

重症の頭部外傷は他の痤縮とは違い, 比較的早期から 強い痤縮をきたすことが多く自律神経障害を伴うことが あり，リハビリテーションに難渋し短期に拘縮を招いて 
Table 1 Characteristics of ITB treatment for severe traumatic brain injury in Kindai University Hospital

\begin{tabular}{c|c|c|c|c|c|c|c|c|c|c}
\hline Case & Age & Gender & Disease & $\begin{array}{c}\text { Intervention } \\
\text { from onset } \\
(\mathrm{M})\end{array}$ & $\begin{array}{c}\text { Onset } \\
\text { GCS }\end{array}$ & $\begin{array}{c}\text { Catheter tip } \\
\text { placement }\end{array}$ & $\begin{array}{c}\text { Baclofen } \\
\text { volume } \\
(\mu \mathrm{g} / \text { day })\end{array}$ & $\begin{array}{c}\text { Autonomic } \\
\text { dysfunction }\end{array}$ & $\begin{array}{c}\text { Preoperative } \\
\text { GOCS }\end{array}$ & $\begin{array}{c}\text { Latest } \\
\text { GOCS }\end{array}$ \\
\hline 1 & 20 & $\mathrm{M}$ & $\mathrm{DAI} \cdot \mathrm{ICH} \cdot \mathrm{IVH}$ & 4.4 & 4 & Cervical & 151 & + & 2 & 3 \\
2 & 24 & $\mathrm{M}$ & $\begin{array}{c}\text { ASDH } \\
\text { Contusion }\end{array}$ & 2.2 & 4 & Cervical & 88 & + & 2 & 3 \\
3 & 20 & $\mathrm{M}$ & $\begin{array}{c}\text { ASDH } \\
\text { Contusion }\end{array}$ & 3.3 & 6 & Cervical & 105 & + & 2 & 3 \\
4 & 20 & $\mathrm{~F}$ & $\mathrm{DAI} \cdot \mathrm{ICH}$ & 1 & 7 & Only screenig & 50 & + & 3 & 5 \\
5 & 7 & $\mathrm{M}$ & $\mathrm{DAI} \cdot \mathrm{SAH}$ & 2 & 4 & Cervical & 95 & + & 2 & 3 \\
\hline
\end{tabular}

ASDH : acute subdural hematoma, DAI : diffuse axonal injury, GCS : Glasgow Coma Scale, GOCS : Glasgow Outcome Scale, $\mathrm{ICH}:$ intracerebral hematoma, IVH : intraventricular hemorrhage, SAH : subarachnoid hemorrhage

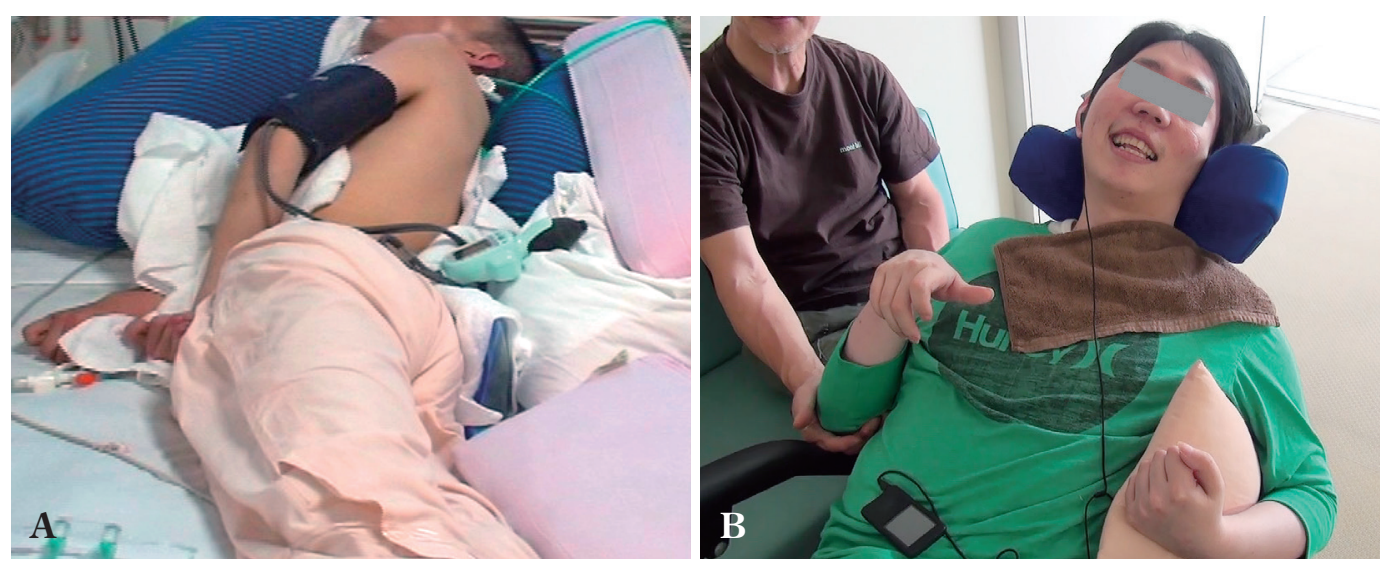

Fig. 3 A 24-year-old patient with tetraparesis after traumatic brain injury (Case 2) A : Before ITB treatment.

B : 6 years after ITB treatment.

しまう。したがって受傷から早期での瘥縮治療介入がリ ハビリテーションを容易にし，意識レベルや運動機能の 著明な改善を得ることが期待される ${ }^{11)}$ 。われわれの施設 で施行した重症頭部外傷に対する 5 症例の一覧を示す

(Table 1).4症例の入院時の意識レベルは Glasgow Coma Scale（GCS）で 4 7 の状態で, 低体温療法後に全身の 筋緊張光進に加え高体温・頻拍・頻呼吸・発汗などの自 律神経障害を認め, リハビリテーションに難渋していた 症例群であった。バクロフェンスクリーニングテストに て筋緊張充進および自律神経障害を一時的に改善した 4 例に対して ITB ポンプ埋め込み術を施行した（Fig. 3,

4). 術後自律神経障害は改善し, 最終的な転帰も Glasgow Outcome Scale で1 段階以上改善した. また, ス クリーニングテスト (バクロフェン $50 \mu \mathrm{g}$ ボーラス投与) のみで筋緊張と自律神経障害が改善し, 意識レベル, 失 語も改善した 1 症例も経験している.

頭部外傷後の自律神経障害は, 皮質および皮質下領域
の障害による血圧/体温調節異常9) と大脳の中枢性交感 神経活動の興奮と脱抑制 ${ }^{5)}$ にり生じるとされており, 自律神経の改善は, バクロフェンの抑制作用が脊髄レベ ルにおける入力刺激系を調節することにより中枢神経で の overload した固有感覚情報の改善によるものではない かと推測している.

これらの結果からも, 重症頭部外傷後の痤縮例に対す る早期バクロフェン髄腔内投与が劇的に著効する場合が あるので, 躊躇せず試みることも重要と考元る.さらに, 重症痓縮や二次性ジストニアに伴う過剩な代謝のために るい瘦状態になりがちである. ITB 療法により代謝立進 を軽減し, るい瘦状態の改善することを報告した ${ }^{37)}$.

\section{3 脊髄損傷}

胸椎レベル以下での損傷例では下肢の痤縮（クローヌ スやスパズム) が主で, ITB 療法により痤縮の改善が得 られ座位での安定性やベッドから車椅子への移動が容易 

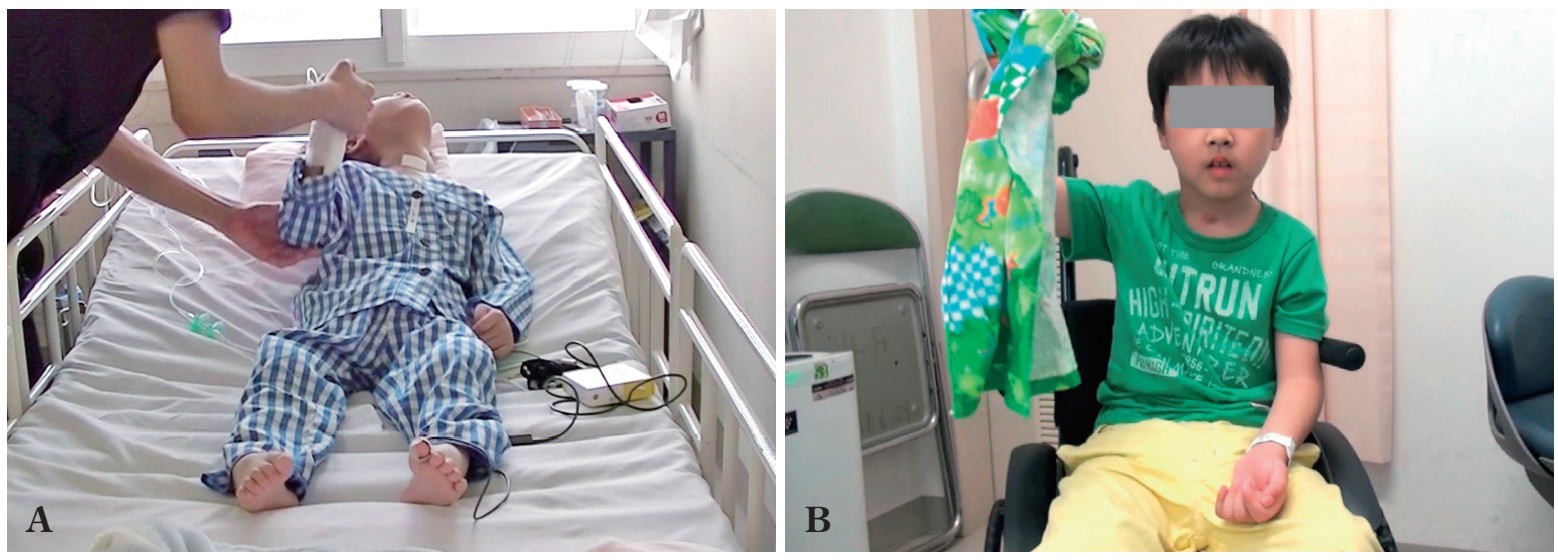

Fig. 4 A 7-year-old patient with tetraparesis after traumatic brain injury (Case 5)

A : Before ITB treatment.

B : 6 months after ITB treatment.

となる。また頝椎レベルでの損傷例では上下肢および体 幹の痉縮に加え損傷部以下の体幹の締女付け感，内臓感 覚異常，神経遮断性の痛みを伴い，呼吸筋群の瘥縮のた め夜間の睡眠障害・低換気をきたすことが多い. ITB 療 法は筋緊張に伴う締め付け感や痛みを軽減し, 呼吸筋群 の痓縮改善により睡眠中の低換気も改善することができ $3^{3) 16(27) 28)}$.

\section{4 痤性対麻痺}

痓性対麻痺の症例では下肢の痓縮軽減を目的にした下 部胸椎カテーテル留置がよい. 歩行可能な症例では術前 痤縮を利用して歩行していたものが㾏縮の軽減により, 潜在する両下肢の筋力低下が表面化し一時的に歩容が増 悪する。このためにバクロフェンの投与量は少量となる

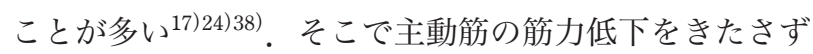
に拮抗筋の共収縮を抑制して随意運動の改善をきたすよ う細かなバクロフェンの投与調節と歩行再教育のための リハビリテーションが重要となる.

\section{5 脳性麻痺}

ITB 療法の適応は小児の痤直型とアテトーゼ型に多 ( ${ }^{6) 1431)}$. ITB療法の効果は, 軽症例では運動機能や歩行 状態が改善され, 重症例では運動機能の改善は低いが, 夜間の睡眠改善や呼吸機能改善を認め ${ }^{16)}$, 介護者の負担 軽減が得られる ${ }^{23)}$. 前述の SDRも同等の治療効果を得る ことができるため, 施設の特徵・環境によりどちらを選 択するか判断する.

\section{A 型ボツリヌス療法（BoNT-A）}

A 型ボッリヌス毒素は筋肉内に投与され，神経筋接合 部に作用し，エンドサイトーシスにより神経終末から細 胞内に取り込まれその一部がタンパクである SNAP-25 を切断しアセチルコリンの放出を抑制し，筋収縮を阻害 することにより痤縮を軽減する。

2010 年 10 月に本邦で上肢痤縮・下肢痤縮に対する BoNT-A 治療が認可され，他の痤縮治療法と比較して圧 倒的に低侵襲で痤縮治療効果が得られると期待され，リ ハビリテーション科医や神経内科医での使用機会が増加 している，主な治療適応は，脳卒中後などの片麻痺に伴 う痤縮や小児脳性麻痺症例に対しての局所性痓縮である。 本邦では 1 回に使用できる量は, 小児の場合は 4 単位/ $\mathrm{kg}$, 上限 200 単位となっており, 成人の最大投与量は上 肢痤縮では 240 単位/回, 下肢痤縮では 300 単位/回と なっており，投与 3 力月間では 360 単位以内と規定され ているために，上下肢同時に施注するには投与量の制限 が生じる。

痤縮による肢位には共通のパターンがあり，上下肢に おける肢位と罹患筋肉および治療による効果の一覧を参 考に（Table 2，3），実際の筋緊張を確認しながら施注を 行う。施注筋が深部筋や前腕部の小さな筋では超音波や 筋電図, 神経筋電気刺激を使用して施注の精度を上げる ことが15)42) 治療効果の向上につながる.

また，投与濃度に関しては，広い範囲に浸透させるに は濃度を薄め, 狭い範囲に効果を留めるためには濃度を 濃くするのがよいといわれている32)。そこで，われわれ の施設では BoNT-A の 100 単位を上肢では $4 \mathrm{ml}$, 下肢で は $8 \mathrm{~m} l$ 程度に溶解し使用している。投与量に関して, 上 
Table 2 Patterns of spasticity and treatment benefits in upper limb

\begin{tabular}{|c|c|c|}
\hline Spasticity in upper limb & Muscle involved & Benefits \\
\hline Shoulder adduction, internal rotation & $\begin{array}{l}\text { Pectoralis major } \\
\text { Latissimus dorsi } \\
\text { Teres muscle group } \\
\text { Subscapularis } \\
\text { Rhomboids and interscapular muscles }\end{array}$ & $\begin{array}{l}\text { Sitting posture } \\
\text { Ease of dressing } \\
\text { Axillary hygiene } \\
\text { Improve balance and symmetry of gait }\end{array}$ \\
\hline Elbow flexion & $\begin{array}{l}\text { Biceps brachii } \\
\text { Brachialis } \\
\text { Brachioradialis }\end{array}$ & $\begin{array}{l}\text { Improve flexion deformity } \\
\text { Improve reach/retrieve }\end{array}$ \\
\hline Pronation of the forearm & $\begin{array}{l}\text { Pronator teres } \\
\text { Pronator quadratus }\end{array}$ & Hand function \\
\hline Flexed wrist and clenched hand & $\begin{array}{l}\text { Flexor carpi ulnaris and radialis } \\
\text { Flexor digitorum superficialis and profundus } \\
\text { Flexor pollicis longus }\end{array}$ & $\begin{array}{l}\text { Maintain palmar skin hygiene } \\
\text { Improve grasp release }\end{array}$ \\
\hline $\begin{array}{l}\text { Thumb in palm, intrinsic muscle } \\
\text { stiffness }\end{array}$ & $\begin{array}{l}\text { Opponens pollicis } \\
\text { Adductor pollicis } \\
\text { Flexor pollicis brevis } \\
\text { Lumbricals } \\
\text { Interossei }\end{array}$ & Improve grasp \\
\hline
\end{tabular}

Table 3 Patterns of spasticity and treatment benefits in lower limb

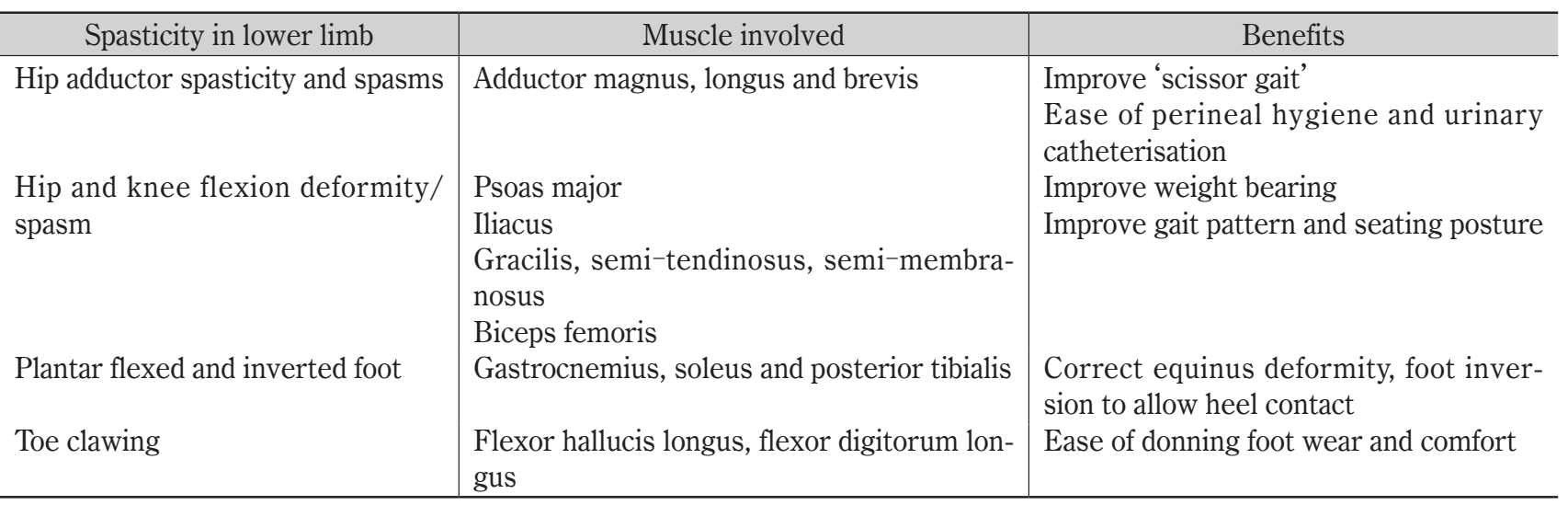

肢では手掌部の虫様筋などの小さな筋であれば 1 筋あた り 10 単位程度, 前腕部の筋であれば 25 単位を目安にし て総量 200 単位を使用することが多い。手関節や手指関 節では関節可動域の向上は期待できるが（Fig. 5A, B), 小さな筋肉は治療時には筋短縮をきたしている場合があ り，機能改善は困難な場合が多い，運動機能の改善はむ しろ大きな筋群が関与する肩や肘運動で期待できる （Fig. 5C，D）。一方，下肢の筋は上肢よりも容量が大き いため, 小さな筋でも 50 単位, 大きな筋であれば 100 単 位を 2〜3 力所に施注して総量 300 単位を使用している. 下肢に関しては，足関節の尖足内反および足趾の claw toe 変形に対して施注されることが多い.

一般的に BoNT-A の臨床効果は 2〜 7 日以降に発現し
3〜4 力月程度効果が持続し ${ }^{1)}$, 治療までの経過が長い場 合は，1回の施注では効果を実感できない場合もあり， 最低でも 3〜4 回は継続する必要はある。

\section{痙縮治療の今後の展望}

痤縮治療を発展させるためには，脳血管障害や頭部外 傷の急性期に関わることの多い脳神経外科医が率先して 痤縮に対する治療法の特徵を知り，患者および患者家族 に回復期および在宅期に生じる痤縮という病態を説明 し，リハビリテーションの重要性のみならず，痤縮に対 する治療法の存在を提示することが重要である.

また，回復期病院においてはリハビリテーションス 

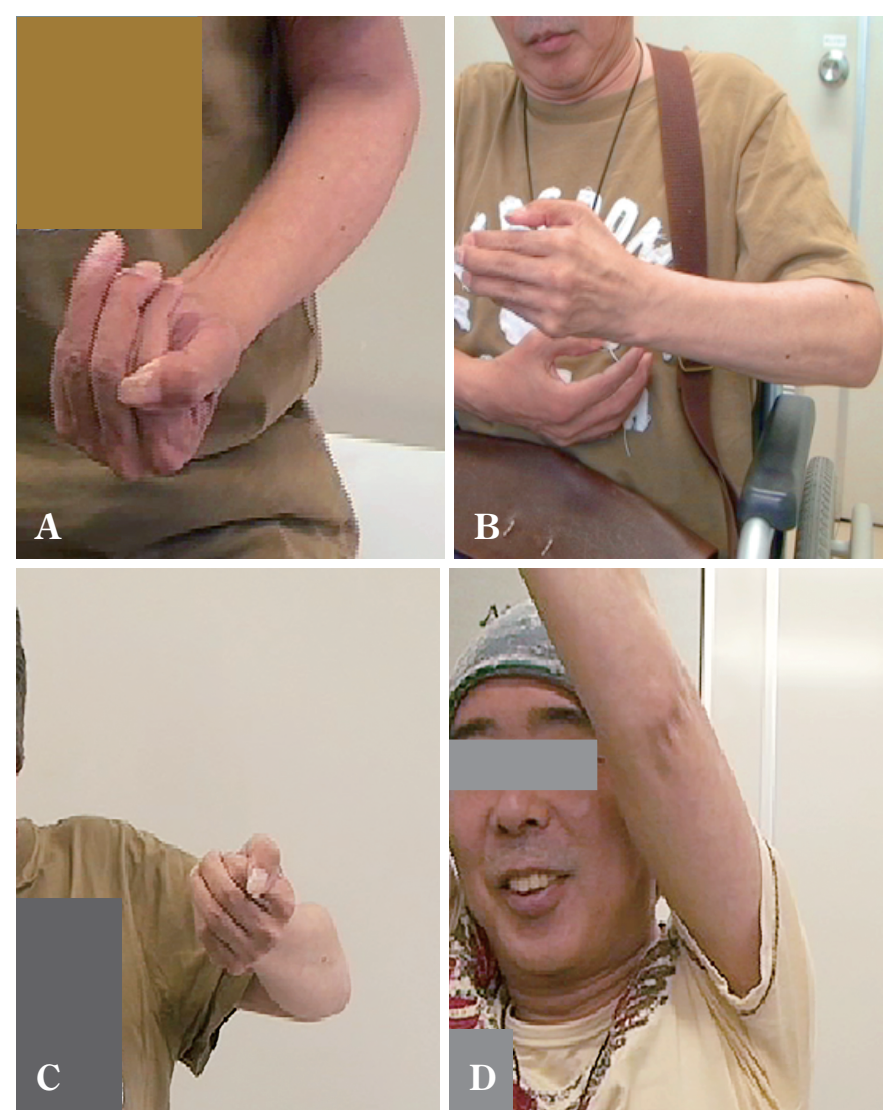

Fig. 5 The posture of the shoulder and finger joint in a patient with left statistic hemiparesis after intracerebral hemorrhage

A, C : Before BoNT-A infusion.

B, D : 6 months after BoNT-A infusion (2 times infusion).

タッフも充実しており神経機能回復もめざましい，しか し, 痤縮は多くの場合回復期を過ぎる発症後 $3 \sim 6$ 力月 頃より出現する病態であるため, 回復期には歩行可能で あり上肢の関節可動域・機能改善をきたしていたもの が，在宅期に痤縮が増悪し ADL，QOL の低下を招いて いる場合が多い。したがって痤縮に対して適切な治療介 入時期を見逃さないためにもメディカルスタッフを含め た一貫した瘥縮治療教育とリハビリテーションを中心と した病診連携を含めた地域連携の体制作りが重要であ り, 脳神経外科医に課せられた使命でもあると考える。

著者全員は日本脳神経外科学会への COI 自己申告を完了し ています。本論文に関して開示すべき COI はありません。

\section{文 献}

1) Aoki KR : Preclinical update on BOTOX ${ }^{\circledast}$ (botulinum toxin type A) purified neurotoxin complex relative to other botu- linum neurotoxin preparations. Eur J Neurol 6 : S3-S10, 1999.

2) Bareyre FM, Kerschensteiner M, Raineteau O, Mettenleiter TC, Weinmann O, Schwab ME: The injured spinal cord spontaneously forms a new intraspinal circuit in adult rats. Nat Neurosci $\quad$ 7:269-277, 2004.

3) Bensmail D, Quera Salva MA, Roche N, Benyahia S, Bohic M, Denys P, Bussel B, Lofaso F : Effect of intrathecal baclofen on sleep and respiratory function in patients with spasticity. Neurology $67:$ 1432-1436, 2006.

4) Berard C, Sindou M, Berard J, Carrier H : Selective neurotomy of the tibial nerve in the spastic hemiplegic child: an explanation of the recurrence. J Pediatr Orthop B 7: 6670, 1998.

5) Boeve BF, Wijdicks EF, Benarroch EE, Schmidt KD : Paroxysmal sympathetic storms ("diencephalic seizures") after severe diffuse axonal head injury. Mayo Clin Proc 73 : 148-152, 1998.

6) Brochard S, Remy-Neris O, Filipetti P, Bussel B : Intrathecal baclofen infusion for ambulant children with cerebral palsy. Pediatr Neurol 40:265-270, 2009.

7) Brown P: Pathophysiolosy of spasticity. J Neurol Neurosurg Psychiatry 57: 773-777, 1994. 
8) Buffenoir K, Roujeau T, Lapierre F, Menei P, Menegalli-Boggelli D, Mertens P, Decq P : Spastic equinus foot : multicenter study of the long-term results of tibial neurotomy. Neurosurgery $55: 1130-1137,2004$.

9) Bullard DE : Diencephalic seizures : responsiveness to bromocriptine and morphine. Ann Neurol $21: 609-611,1987$.

10) Chrysagis N, Skordilis EK, Tsiganos G, Koutsouki D : Validity evidence of the Lateral Step Up (LSU) test for adolescents with spastic cerebral palsy. Disabil Rehabil $\quad 35: 875^{-}$ 880, 2013.

11) Cuny E, Richer E, Castel JP : Dysautonomia syndrome in the acute recovery phase after traumatic brain injury: relief with intrathecal baclofen therapy. Brain Inj 15: 917-925, 2001.

12) Decq P, Filipetti P, Cubillos A, Slavov V, Lefaucheur JP, Nguyen JP : Soleus neurotomy for treatment of the spastic equinus foot. Groupe d'Evaluation et de Traitement de la Spasticité et de la Dystonie. Neurosurgery $\quad 47: 1154-1160$, 2000.

13) Deitombe T, Gustin T, Laloux P, De Cloedt P, De Wispelaere JF, Hanson P: Selective fasicular neurotomy for spastic equinovarus foot deformity in cerebral palsy children. Acta Orthop Belg 67: 1-5, 2001.[Article in French]

14) Gray N, Morton RE, Brimlow K, Keetley R, Vloeberghs M : Goals and outcomes for non ambulant children receiving continuous infusion of intrathecal baclofen. E J Paediatr Neurol 16: 443-448, 2012.

15) Haig AJ, Goodmurphy CW, Harris AR, Ruiz AP, Etemad J : The accuracy of needle placement in lower-limb muscles : a blinded study. Arch Phys Med Rehabil 84: 877-882, 2003.

16) Kishima H, Yanagisawa T, Goto Y, Oshino S, Maruo T, Tani N, Khoo HM, Hosomi K, Hirata M, Yoshimine T : Respiratory function under intrathecal baclofen therapy in patients with spastic tetraplegia. Neuromodulation 19:650-654, 2016.

17) Klebe S, Stolze H, Kopper F, Lorenz D, Wenzelburger R, Deuschl G, Volkmann J : Objective assessment of gait after intrathecal baclofen in hereditary spastic paraplegia. $J$ Neurol 252: 991-993, 2005.

18) Lance JW : Symposium Synopsis. in Feldman RG, Young RR, Koella WP (eds) : Spasticity: Disordered Motor Control. Chicago, Year Book Medical Publishers, 1980, pp.485-494.

19) Langreak NG, Hillier SL, Verkoeijen PP, Peter JC, Fieggen AG, Vaughan CL: Level of activity and participation in adults with spastic diplegia 17-16 years after selective dorsal rhizotomy. J Rehabil Med $\quad 43:$ 330-337, 2011.

20) Latash ML, Penn RD, Corcos DM, Gottlieb GL: Effect of intrathecal baclofen on voluntary motor control in spastic paresis. J Neurosurg $\mathbf{7 2}:$ 388-392, 1990.

21) Levi R, Hultling C, Seiger A : The Stockholm Spinal Cord Injury Study : 2. Associations between clinical patient characteristics and post-acute medical problems. Paraplegia 33: 585-594, 1995.

22) MacWilliams BA, Johnson BA, Shuckra AL, D’Astous JL: Functional decline in children undergoing selective dorsal rhizotomy after age 10. Dev Med Child Neurol $53: 717-$ 723, 2011.

23) McCarty SF, Gaebler-Spira D, Harvey RL : Improvement of sleep apnea in a patient with cerebral palsy. Am J Phys Med Rehabil 80:540-542, 2001.

24) Meythaler JM, Steers WD, Tuel SM, Cross LL, Haworth CS: Intrathecal baclofen in hereditary spastic paraparesis. Arch Phys Med Rehabil 73 : 794-797, 1992.
25) Meythaler JM, Guin-Renfroe S, Brunner RC, Hadley MN : Intrathecal baclofen for spastic hypertonia from stroke. Stroke 32: 2099-2109, 2001.

26) Mukherjee A, Chakravarty A: Spasticity mechanisms - for the clinician. Front Neurol $\quad \mathbf{1}:$ 149, 2010.

27) Ochs G, Struppler A, Meyerson BA, Linderoth B, Gybels J, Gardner BP, Teddy P, Jamous A, Weinmann P: Intrathecal baclofen for long-term treatment of spasticity: a multi-center study. J Neurol Neurosurg Psychiatry 52:933-939, 1989.

28) Ordia JI, Fischer E, Adamski E, Spatz EL : Chronic intrathecal delivery of baclofen by a programmable pump for the treatment of severe spasticity. J Neurosurg 85:452-457, 1996.

29) Pandyan A, Gregoric M, Barnes M, Wood D, Van Wijck F, Burridge J, Hermens H, Johnson GR : Spasticity : clinical perceptions, neurological realities and meaningful measurement. Disabil Rehabil $27: 2-6,2005$.

30) Paty DW, Ebers GC : Clinical features. in Multiple Sclerosis. Philadelphia, FA Davis Company, 1998, pp.135-192.

31) Ramstad K, Jahnsen R, Lofterod B, Skjeldal OH : Continuous intrathecal baclofen therapy in children with cerebral palsy - when does improvement emerge? Acta Paediatr 99: 1661-1665, 2010.

32) Shaari CM, George E, Wu BL, Biller HF, Sanders I : Quantifying the spread of botulinum toxin through muscle fascia. Laryngoscope 101:960-964, 1991.

33) Sheean G: The pathophysiology of spasticity. Eur J Neurol 9 suppl 1:3-9, 2002.

34) Sheehan G : Neurophysiology of Spasticity. in Barnes MP, Johnson GR (eds): Upper Motor Neuron Syndrome and Spasticity: Clinical Management and Neurophysiology, 2nd edition. Cambridge, Cambridge University Press, 2008, pp.9-63.

35) Sindou M, Martens F : Selective neurotomy of the tibial nerve for treatment of the spastic foot. Neurosurgery $\mathbf{2 3}$ : 738-744, 1998.

36）平 孝臣, 赤川浩之, 岡田芳和, 上川秀士, 堀 智勝: 本邦における痮縮の疫学的調査. リ八医 $37: 863,2003$.

37) Uchiyama T, Nakanishi K, Fukawa N, Yoshioka H, Murakami $\mathrm{S}$, Nakano N, Kato A : Neuromodulation using intrathecal baclofen therapy for spasticity and dystonia. Neurol Med Chir (Tokyo) 52: 463-469, 2012.

38）内山卓也, 加藤天美: ITB による痠縮治療の適応と効果. 脳外誌 $25: 149-156,2016$.

39) van Kuijk AA, Hendricks HT, Pasman JW, Kremer BH, Geurts AC: Are clinical characteristics associated with upper-extremity hypertonia in severe ischaemic supra-tentorial stroke? J Rehabil Med $\quad 39:$ 33-37, 2007.

40) Verplancke D, Snape S, Salisbury CF, Jones PW, Ward AB : A randomized controlled trial of botulinum toxin on lower limb spasticity following acute acquired severe brain injury. Clin Rehabil 19: 117-125, 2005.

41) Watkins C, Leathley MJ, Gregson JM, Moore AP, Smith TL, Sharma AK : Prevalence of spasticity post stroke. Clin Rehabil 16:515-522, 2002.

42) Wissel J, Ward AB, Erztgaard P, Bensmail D, Hecht MJ, Lejeune TM, Schnider P, Altavista MC, Cavazza S, Deltombe T, Duarte E, Geurts AC, Gracies JM, Haboubi NH, Juan FJ, Kasch H, Kätterer C, Kirazli Y, Manganotti P, Parman Y, Paternostro-Sluga T, Petropoulou K, Prempeh R, Rousseaux M, Slawek J, Tieranta N : European consensus 
table on the use of botulinum type A in adult spasticity. $J$

Rehabil Med 41: 13-25, 2009.
43) Young RR: Spasticity : a review. Neurology 44 (11 Suppl 9) : S12-S20, 1994.

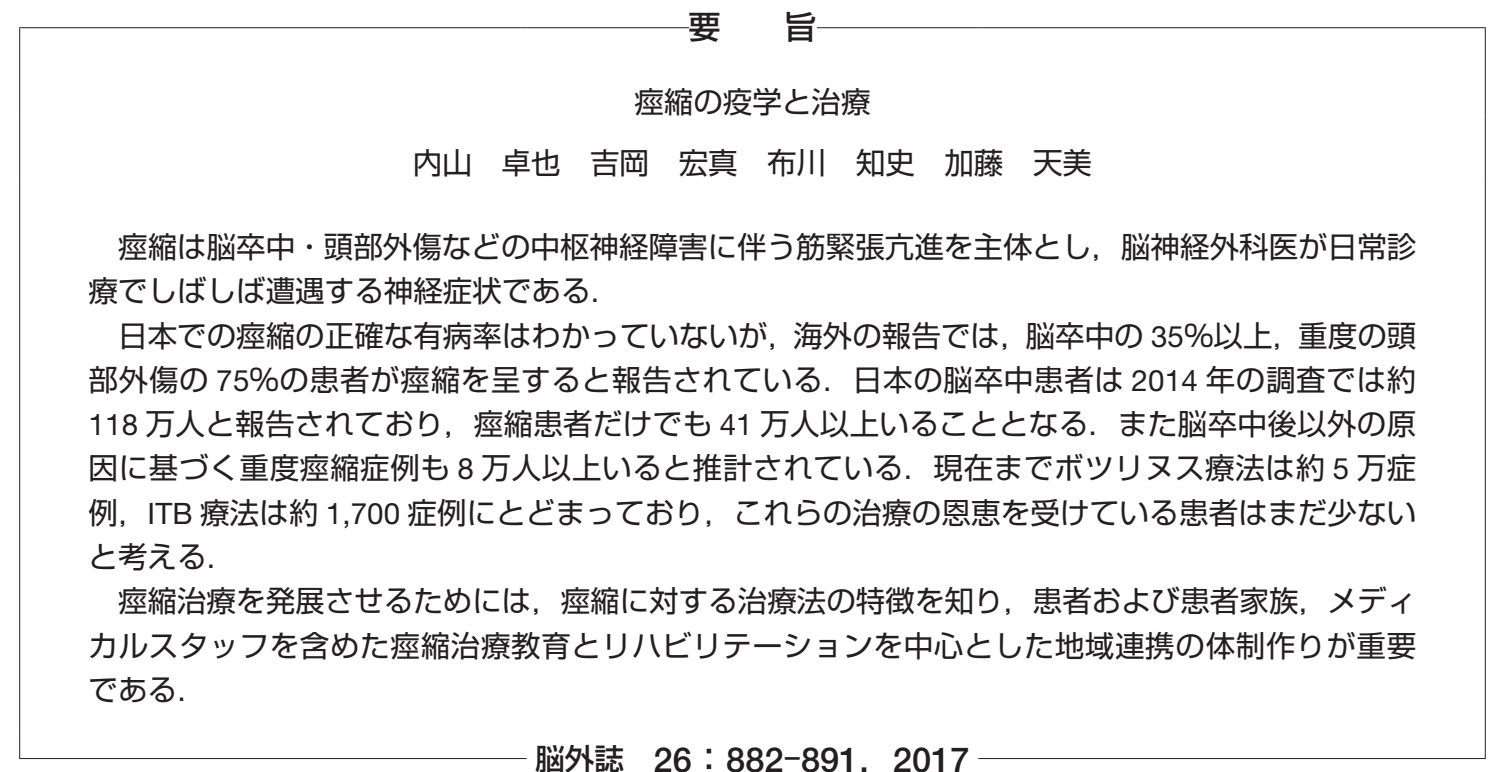

